\title{
A Study on Genotypic Evaluation of Green Gram (Vigna radiata L.) in respect of Yield and Yield-Attributing Traits in the Coastal Saline belts of Sundarbans, West Bengal
}

\author{
Shyam Sundar Lakshman', Nihar Ranjan Chakrabarty ${ }^{2}$, Praresh Chandra Kole ${ }^{3}$ \\ ${ }^{1}$ All India Coordinated Research Project-Sunflower, Nimpith-743338, 24 Parganas (S), West Bengal \\ ${ }^{2,3}$ Department of Genetics, Plant Breeding and Crop Physiology, Institute of Agriculture, Palli Siksha \\ Bhavana, Visva-Bharati-731236 \\ *Corresponding Author(Email: lakshmanshyam_ss@yahoo.co.in)
}

How to cite this paper: Lakshman, S.S., Chakrabarty, N.R. and Kole, P.C. (2019). A Study on Genotypic Evaluation of Green Gram (Vigna radiata $\mathrm{L}$.) in respect of Yield and Yield-Attributing Traits in the Coastal Saline belts of Sundarbans, West Bengal. Grassroots Journal of Natural Resources, 2(4): 38-44. Doi:

https://doi.org/10.33002/nr2581.6853.02044

Received: 05 October 2019

Reviewed: 29 October 2019

Provisionally Accepted: 07 November 2019

Revised: 20 November 2019

Finally Accepted: 15 December 2019

Published: 31 December 2019

Copyright $\odot 2019$ by author(s) and

The Grassroots Institute.

This work is licensed under the Creative Commons Attribution International License (CC BY 4.0).

http://creativecommons.org/licenses/by/4.0/
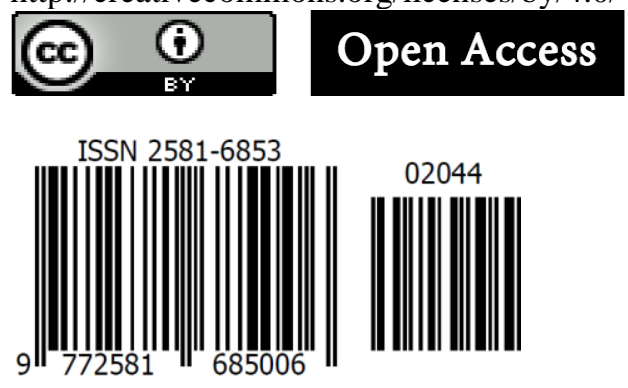

\begin{abstract}
A field experiment was carried out at Ramkrishna Ashram KVK Instructional Farm, Nimpith, South 24Parganas during the pre-kharif season, 2012 to evaluate the performance of 66 numbers of green gram (Vigna radiata $\mathrm{L}$.) genotypes in low to medium saline soil in coastal saline belts of Sundarbans, West Bengal. Almost all the 66 cultivars selected for the experiments took 5-6 days for $75 \%$ germination of seedlings and 2736 days to achieve $50 \%$ flowering. Final plant stand count was from $70-80 \%$. The higher value of seed yield was observed in PUSA-2031 (1398 kg), 75.4\% higher in comparison to the local check Chaiti moong $(797 \mathrm{~kg} / \mathrm{ha})$ followed by KM-11-573 (1302 kg; $63.3 \%$ more than LC), SM-11-41 (1286 kg; 61.3\% more than LC), KM$11-583(1280 \mathrm{~kg}, 60.6 \%$ more than LC), KM-11-578 $(1211 \mathrm{~kg}, 51.9 \%$ more than LC), respectively. The significantly higher values of other yield attributing traits were observed among the green gram genotypes. In case of root length, the above genotypes were found significantly lower $(12.33-14.33 \mathrm{~cm}, 7.8-20.4 \%)$ than the Chaiti moong (LC) $15.5 \mathrm{~cm}$. From the above experiment it may be concluded that in the similar situation as well as soil salinity condition the above green gram genotypes may prove to perform better than the local cultivar Chaiti moong for cultivation in the coastal saline regions of Sundarbans, West Bengal.
\end{abstract}

\section{Keywords}

Green gram; Seed yield; Salinity; Sundarbans 
Doi: https://doi.org/10.33002/nr2581.6853.02044

\section{Introduction}

Indian population is predominantly vegetarian. Protein requirement for the growth and development of the human being is mostly met by the pulse. Among the pulses, green gram (Vigna radiata L.) is one of the rich sources of protein (25\%), carbohydrate, minerals, especially $\mathrm{Ca}$ $(0.15 \%)$, and fat etc. Being a leguminous crop, it has the capacity to fix the atmospheric nitrogen and it also helps in preventing soil erosion. Being deep rooted crop, green gram is highly adaptive to rainfed areas. Due to shorter duration, it fits well in cropping system and gives extra benefits to the farmers in a short period.

Mung bean is a self-pollinated warm season crop. The total pulse production in the country was 13.38 million tons from 22.47 million ha area in the year 2004-05. It is estimated that the country's population will reach nearly 1350 million by 2020 AD. The country needs 30.3 million of pulses to meet the demand. In West Bengal, production of pulses is about 158.02 thousand metric ton from an area of 200.943 thousand hectares. Among the pulses, mung bean produced was 16.048 thousand metric ton from an area of 34.99 thousand hectares in rabi (summer) season in the year 2008-09. To meet the call of the future, the area under production and the productivity of green gram should be increased. In West Bengal, mung is largely grown as a summer crop under rainfed conditions and yield is influenced due to erratic monsoon; so, the scope of increasing area under pre-kharif groundnut is limited. In the southern parts of South 24 Parganas district, i.e. parts of Sundarbans, the agriculture faces three-way hindrances. These are i) soil salinity, ii) late release of land for rabi crop due to poor drainage system along with low percolation rate of water, and iii) poor irrigation facility as the ground water is saline and unfit for irrigation. Therefore, the farmers of this region have a very less mobility in crop selection for the rabi season after Aman paddy. In this crop selection process, one should keep in mind that the crop should bear the following characters: a) it is able to grow with minimum irrigation (drought condition) facilities and should survive water stress, b) can tolerate soil salinity to some extent, and c) can protect the soil from direct sun by covering the soil surface, thus minimizing soil salinization process. Like other crops, mung bean also prefers low saline and highly nutritious soil having one or two light irrigations, which facilitates habbock production. However, the yield potential of this crop grown during summer can be realized to a greater extent by adopting suitable water and nutrient management practices. According to Ghassemi, Jackman and Nix (1995), soil salinity is one of the world's major environmental problems. About 7\% of the world's total land area is affected by salt. But, unlike other crops, mung bean can grow well in moderate type soil with at least one life saving irrigation facility as green gram is a somewhat drought tolerant crop. In Sundarban soil, mung bean has enough scope because Sundarban has its own peculiarity with respect to its salinity development. In any plant species, sensitivity to salinity is known to vary between growth stages (Mass and Hoffman, 1977). It has been observed that, just after harvesting of paddy particularly in the month of December, there is very little or no salinity in the soil. But, gradually, when the upper surface of the soil starts drying, some of the plots become saline due to the upward movement of saline groundwater. In this situation, cultivation of mung bean immediately after harvesting of Aman paddy can save both the soil and the crop as well. Mung bean is a good economic crop in this situation, as it gives the farmer to earn some money at a time when no other crop was possible due to lack of irrigation facility. Also, it gives a good fodder during the drier months of March to May, when scarcity of green fodder is acute in this region. Thirdly, it improves soil health by minimizing soil salinity and by nitrogen fixation through symbiotic association with Rhizobium. 
In Sundarban situation, mung bean has been tried for many years, particularly by the farmers who have low to marginal land as well as limited irrigation facilities. It has been noticed that in less saline plots, bumper seed yield has been recorded; whereas in saline plots though the plant growth is good, seed production is not satisfactory. In this context, a systematic study was essential to find out the threshold level of salinity tolerance of this crop and identification of a suitable variety which can grow better in saline condition in coastal saline belts of West Bengal. Still now, no systematic study in this respect has been carried out to find out the optimum level of salinity which the crop can tolerate. In this study, authors tried to find out suitable salt tolerant genotypes to be grown in pre-kharif season under rainfed condition for cultivation in coastal saline belts of West Bengal, especially, in Sundarban areas.

\section{Materials \& Methods}

Present investigation was carried out during pre-kharif (summer) season at the instructional farm of Ramkrishna Ashram Krishi Vigyan Kendra, Nimpith, 24 Parganas (South), West Bengal. The experimental site was situated at $22^{0} 3^{\prime \prime} \mathrm{N}$ latitude and $89^{\circ} 4^{\prime \prime} \mathrm{E}$ longitude and at an altitude of 5.0 $\mathrm{m}$ above mean sea level. The soil of experimental plots was clay loam. The experiment was conducted in Randomized Block Design with three replications. All the ten plots had more or less similar nutritional and $\mathrm{pH}$ level. The genotypes were collected from Indian Institute of Pulse Research (IIPR), Kanpur (ICAR) and West Bengal Pulse \& Oilseed Research Station, Baharampur.

Table 1: Soil nutrient status of eight of 10 randomly selected plots

\begin{tabular}{|l|l|l|l|l|l|l|}
\hline Treatments & $p H$ & $\begin{array}{c}\text { Salinity }(\mathrm{EC}) \\
(\mathrm{dS} / \mathrm{m})\end{array}$ & $\%$ of OC & $\mathrm{N}_{2}(\mathrm{~kg} / \mathrm{ha})$ & $\mathrm{P}_{2} \mathrm{O}_{5}(\mathrm{~kg} / \mathrm{ha})$ & $\mathrm{K}_{2} \mathrm{O}(\mathrm{kg} / \mathrm{ha})$ \\
\hline $\mathrm{T}_{1}$ & 6.65 & 1.28 & 0.85 & 625.2 & 91.6 & 478.6 \\
\hline $\mathrm{T}_{2}$ & 6.82 & 1.45 & 0.89 & 595.6 & 88.2 & 456.8 \\
\hline $\mathrm{T}_{3}$ & 7.04 & 1.63 & 0.86 & 563.6 & 89.7 & 443.5 \\
\hline $\mathrm{T}_{4}$ & 6.86 & 1.85 & 0.78 & 542.9 & 79.6 & 451.6 \\
\hline $\mathrm{T}_{5}$ & 6.98 & 2.06 & 0.81 & 556.1 & 83.4 & 411.8 \\
\hline $\mathrm{T}_{6}$ & 6.82 & 2.26 & 0.80 & 510.7 & 80.5 & 403.2 \\
\hline $\mathrm{T}_{7}$ & 6.88 & 2.37 & 0.84 & 537.4 & 78.8 & 436.2 \\
\hline $\mathrm{T}_{8}$ & 7.01 & 2.49 & 0.80 & 513.5 & 81.3 & 468.8 \\
\hline $\mathrm{T}_{9}$ & 6.92 & 2.58 & 0.76 & 532.2 & 78.2 & 423.6 \\
\hline $\mathrm{T}_{10}$ & 7.02 & 2.70 & 0.85 & 560.6 & 85.9 & 431.7 \\
\hline
\end{tabular}

Each subplot was of $3.0 \mathrm{~m}$ in width and $3.0 \mathrm{~m}$ in length. Seeds were drilled $5-6 \mathrm{~cm}$ apart during $28^{\text {th }}$ February and row to row spacing was given $60 \mathrm{~cm}$. At the time of land preparation FYM was applied at rate of $15 \mathrm{ton} / \mathrm{ha}$. Common dose of $25 \mathrm{~kg} \mathrm{~N}$ and $50 \mathrm{~kg} \mathrm{P}_{2} \mathrm{O}_{5} / \mathrm{ha}$ and $40 \mathrm{~kg} \mathrm{~K} / \mathrm{O} / \mathrm{ha}$ was applied in the form of urea, SSP and MOP as basal. The crop was grown in rainfed condition. There was little rain $(20 \mathrm{~mm})$ during the crop period. The meteorological data is given below. Observations were recorded from 10 representative plants selected randomly from each replication on the following set of characters viz. germination $\%$, final plant height $(\mathrm{cm})$, number of branches/plant, leaf area $\left(\mathrm{cm}^{2}\right)$ per plant, days to 50\% flowering, number of pods per plant, pod length at maturity, number of seeds per pod, 100 seed weight $(\mathrm{g})$, seed yield per plant (g), seed yield (kg/ha). Leaf area was calculated by multiplying number of leaves in the plant and average 
Doi: https://doi.org/10.33002/nr2581.6853.02044

individual leaf size. The shoot and root characteristics were studied when the genotypes were grown in laboratory condition (upto 7-8 days).

\section{Result and Discussion}

Almost all the 66 cultivars selected for the experiments took 5-6 days for $75 \%$ germination of seedlings and 28-41 days to achieve 50\% flowering. Final plant stand count was $70-80 \%$. The salinity of all the plots were studied before sowing and after harvesting the crop. The salinity range (EC) of soil before sowing was $0.2 \mathrm{ds} / \mathrm{m}$ to $1.2 \mathrm{ds} / \mathrm{m}$, and total salt was $100 \mathrm{ppm}$ to $300 \mathrm{ppm}$. After harvesting the crop, soil salinity (EC) ranged from $0.6 \mathrm{ds} / \mathrm{m}$ to $2.2 \mathrm{ds} / \mathrm{m}$, and total salt was $230 \mathrm{ppm}$ to $960 \mathrm{ppm}$. The final plant height of moong bean varied significantly from genotype to genotype. The range of the plant height varies from $33 \mathrm{~cm}$ to $62.8 \mathrm{~cm}$. The minimum plant height was recorded in the genotype in SM-11-50 $(33 \mathrm{~cm})$ and maximum plant height was recorded in the genotype KM-11-587 $(62.8 \mathrm{~cm})$. The higher plant height was observed in the genotypes which took more days to flower. Leaf area per plant of moong bean varied significantly from genotype to genotype. The range of LAI varied from 20.5 (SM-11-50) to 142.5 (KM-11-586). Here the $\mathrm{pH}$, organic carbon, available nitrogen, phosphate and potash had insignificant variation in different treatment levels. Therefore, it can be concluded that only the genetical background and differences of the moong bean cultivars was the limiting factor on the growth and seed yield of moong bean.

Table 2: Weather data during the investigation period (December 2011 - June 2012)

\begin{tabular}{|l|c|c|c|c|c|}
\hline \multirow{2}{*}{ Month } & \multicolumn{2}{|c|}{ Temperature $\left({ }^{0} \mathrm{C}\right)$} & & \multicolumn{2}{c|}{ Relative Humidity (\%) } \\
\cline { 2 - 6 } & Maximum & Minimum & $\begin{array}{c}\text { Rainfall } \\
(\mathrm{mm})\end{array}$ & Maximum & Minimum \\
\hline Dec 2011 & 228.8 & 10.0 & - & 94.5 & 29.5 \\
\hline Jan 2012 & 27.5 & 10.2 & - & 93 & 26 \\
\hline Feb 2012 & 32.5 & 11.9 & - & 98 & 26 \\
\hline Mar 2012 & 38.5 & 21.5 & - & 98 & 23 \\
\hline Apr 2012 & 39.5 & 22.6 & 4.0 & 99 & 30 \\
\hline May 2012 & 38.6 & 23.0 & 180.5 & 99 & 31 \\
\hline June 2012 $\left(1^{\text {st }}\right.$ week) & 37.4 & 22.7 & 96.4 & 99 & 51 \\
\hline
\end{tabular}

Table 3: Analysis of Variance Table for Yield attributing Traits

\begin{tabular}{|l|l|l|l|l|l|l|}
\hline \multicolumn{1}{|c|}{ Source } & d.f. & $\begin{array}{c}\text { Seed yield } \\
(\mathrm{kg} / \mathrm{ha})\end{array}$ & $\begin{array}{c}\text { No. of } \\
\text { pods/plant }\end{array}$ & $\begin{array}{c}\text { No. of seeds } \\
\text { /pod }\end{array}$ & $\begin{array}{c}\text { Pod length } \\
(\mathrm{cm})\end{array}$ & $\begin{array}{c}100 \text { seed } \\
\text { weight }(\mathrm{g})\end{array}$ \\
\hline MS (Rep.) & 2 & 9801 & 14.2 & 10.24 & 4.06 & $0.81^{*}$ \\
\hline MS (Tr.) & 15 & $47724^{* *}$ & $80.20^{* *}$ & $38.26^{* *}$ & $11.7 * *$ & $1.49^{* *}$ \\
\hline MS (Error) & 30 & 40.33 & 0.57 & 1.57 & 0.34 & 0.21 \\
\hline
\end{tabular}

The result of experiment has clearly highlighted the seed yield per plant and seed yield per hectare varied significantly from genotype to genotype. Among all the genotypes under study the significantly higher value of seed yield per hectare was observed in PUSA-2031 (1398 kg,) which was $75.4 \%$ higher in comparison to the local check, i.e. Chaiti moong seed yield was recorded 797 $\mathrm{kg} / \mathrm{ha}$ followed by KM-11-573 (1302 kg; 63.3\%), SM-11-41 (1286kg; 61.3\%), KM-11-583 (1280kg, 60.6\%), KM-11-578 (1211 kg, 51.9\%), respectively. Number of pods per plant and number of seeds per pod varied significantly from genotype to genotype. Significantly higher 
Doi: https://doi.org/10.33002/nr2581.6853.02044

values of other yield attributing traits like pod length was recorded among the above genotypes and the range varied from 8.6 to $11.8 \mathrm{~cm}$, an increase by $10-34 \%$ against Chaiti moong whose pod length was recorded $7.2 \mathrm{~cm}$.

Table 4: Promising Genotypes of Green gram evaluated from the trial at RAKVK, Nimpith During Summer 2012

\begin{tabular}{|c|c|c|c|c|c|c|c|c|c|}
\hline $\begin{array}{l}\text { Sl. } \\
\text { No }\end{array}$ & $\begin{array}{l}\text { Name of the } \\
\text { variety }\end{array}$ & $\begin{array}{l}\text { Avg. } \\
\text { yield/(g) } \\
3.6 \mathrm{~m}^{2} \\
\text { plot }\end{array}$ & $\begin{array}{l}\text { Avg. } \\
\text { seed } \\
\text { yield } \\
(\mathrm{kg} / \mathrm{ha})\end{array}$ & $\begin{array}{l}\text { Total } \\
\text { no. of } \\
\text { pods/ } \\
\text { plant }\end{array}$ & $\begin{array}{l}\text { No. } \\
\text { of } \\
\text { seeds } \\
\text { /pod }\end{array}$ & $\begin{array}{l}\text { Pod } \\
\text { length } \\
(\mathrm{cm})\end{array}$ & $\begin{array}{l}100 \\
\text { seed } \\
\text { weight } \\
\text { (g) }\end{array}$ & $\begin{array}{l}\text { Root } \\
\text { length } \\
(\mathrm{cm})\end{array}$ & $\begin{array}{l}\text { No. of } \\
\text { root } \\
\text { branch/ } \\
\text { plant }\end{array}$ \\
\hline 1. & SM-11-44 & 420.0 & 1166.67 & 31.33 & 10.5 & 6.7 & 3.15 & 15.5 & 11.8 \\
\hline 2. & SM-11-41 & 463.0 & 1286.10 & 29.00 & 11.1 & 8.6 & 5.10 & 12.5 & 7.3 \\
\hline 3. & SM-11-38 & 426.3 & 1183.33 & 38.33 & 10.8 & 7.7 & 3.87 & 12.1 & 6.5 \\
\hline 4. & SM-11-45 & 427.0 & 1186.11 & 33.00 & 11.5 & 7.2 & 3.82 & 11.7 & 6.8 \\
\hline 5. & SM-11-24 & 420.0 & 1166.67 & 31.00 & 11.5 & 7.6 & 4.31 & 13.0 & 6.9 \\
\hline 6. & KM-11-557 & 417.0 & 1158.33 & 27.00 & 10.8 & 7.0 & 3.20 & 13.9 & 8.2 \\
\hline 7. & KM-11-578 & 436.0 & 1211.10 & 31.33 & 9.8 & 7.1 & 4.42 & 14.3 & 5.5 \\
\hline 8. & KM-11-583 & 461.0 & 1280.55 & 33.67 & 10.8 & 8.1 & 4.83 & 13.3 & 5.9 \\
\hline 9. & KM-11-573 & 469.0 & 1302.77 & 32.00 & 11.9 & 8.0 & 4.24 & 12.3 & 7.1 \\
\hline 10. & KM-11-563 & 410.3 & 1139.71 & 26.67 & 10.3 & 8.3 & 4.89 & 11.5 & 9.5 \\
\hline 11. & KM-11-587 & 433.3 & 1202.77 & 26.00 & 10.3 & 6.9 & 3.18 & 13.0 & 8.5 \\
\hline 12. & PUSA-2031 & 503.3 & 1398.05 & 36.67 & 11.7 & 7.3 & 4.78 & 14.3 & 11.1 \\
\hline 13. & ML-5 & 434.0 & 1205.55 & 37.33 & 10.9 & 7.1 & 3.98 & 14.2 & 6.8 \\
\hline 14. & KM-52 & 430.0 & 1194.44 & 41.67 & 9.5 & 6.9 & 3.77 & 11.8 & 9.7 \\
\hline 15. & VM-44-97-1 & 402.00 & 1116.66 & 24.00 & 10.2 & 6.7 & 3.92 & 9.83 & 11.7 \\
\hline \multicolumn{2}{|c|}{$\begin{array}{l}\text { Chaiti Moong } \\
\text { (Local Check) }\end{array}$} & 287 & 797.22 & 24.67 & 10.5 & 6.5 & 2.65 & 15.5 & 5.1 \\
\hline \multicolumn{2}{|c|}{$\mathrm{CD}(5 \%)$} & & 114.2 & 2.68 & 0.57 & 0.63 & 0.25 & 0.82 & 1.72 \\
\hline \multicolumn{2}{|r|}{ C.V (\%) } & & 9.7 & 7.2 & 6.24 & 3.42 & 4.58 & 7.46 & 6.58 \\
\hline
\end{tabular}

All the 66 genotypes were highly significant in respect to the 100 seed weight $(\mathrm{g})$. The range of the 100 seed weight varied from 4.45 to $5.16 \mathrm{~g}$, an increase by $78-106 \%$ against Chaiti moong, whose 100 seed weight was recorded $2.65 \mathrm{~g}$. The range of the pods per plant varied from 26.0 to 33.6 among the above genotypes, an increase by $13-46 \%$ against Chaiti moong, whose numbers of pod per plant was recorded 23 only. The root length of the genotypes varied significantly among the above genotypes. In case of root length the above genotypes were found significantly lower than the local check and it ranged from 12.33 to $14.33 \mathrm{~cm}, 7.8-20.4 \%$ lower than the Chaiti moong (LC) whose root length per plant was recorded $15.5 \mathrm{~cm}$ only. But in case of number of root branches/plant, the above genotypes were found significantly higher and it ranged from 6.3 to 11.0, an increase by $21-115 \%$ over the Chaiti moong (LC) whose root branches/plant recorded only 5.2. The salinity of the fields before sowing the salinity (EC) ranged from 0.27 to $0.38 \mathrm{dS} / \mathrm{m}$, and after harvesting the crop the salinity ranged from (EC) 0.76 to $01.22 \mathrm{dS} / \mathrm{m}$. The salinity of the field where the above genotypes were grown was found not significantly different from the field before sowing where Chaiti moong (EC $0.3 \mathrm{dS} / \mathrm{m}$ ) were sown. 
Doi: https://doi.org/10.33002/nr2581.6853.02044

Table 5: Promising Genotypes of Green gram evaluated from the trial at RAKVK During Summer 2012, and response to salinity in Laboratory Conditions

\begin{tabular}{|c|c|c|c|c|c|c|c|c|c|c|}
\hline \multirow{2}{*}{$\begin{array}{l}\text { Sl. } \\
\text { No. }\end{array}$} & \multirow{2}{*}{$\begin{array}{l}\text { Name of the } \\
\text { Variety }\end{array}$} & \multirow{2}{*}{$\begin{array}{l}\text { Avg. } \\
\text { seed } \\
\text { yield } \\
(\mathrm{kg} / \mathrm{ha})\end{array}$} & \multirow[b]{2}{*}{$\begin{array}{l}\text { Salinit } \\
\text { y }(E C) \\
\text { ds/m } \\
\text { Before } \\
\text { sowing }\end{array}$} & \multirow[b]{2}{*}{$\begin{array}{l}\text { Total } \\
\text { salt } \\
\text { (ppm) } \\
\text { Before } \\
\text { sowing }\end{array}$} & \multirow{2}{*}{$\begin{array}{l}\text { Salinit } \\
\text { y (EC) } \\
\text { ds } / \mathrm{m} \text { at } \\
\text { harvest }\end{array}$} & \multirow[b]{2}{*}{$\begin{array}{l}\text { Total } \\
\text { salt } \\
\text { (ppm) } \\
\text { At } \\
\text { harvest }\end{array}$} & \multicolumn{2}{|c|}{ Shoot length } & \multicolumn{2}{|c|}{ Root length } \\
\hline & & & & & & & $\begin{array}{l}\text { EC } \\
(3.5 \\
\text { dS/m) }\end{array}$ & $\begin{array}{l}\text { Control } \\
\text { (DD } \\
\text { water) } \\
\text { EC }(0.0 \\
\text { dS/m) }\end{array}$ & $\begin{array}{l}\text { EC } \\
(3.5 \\
\text { dS/m) }\end{array}$ & $\begin{array}{l}\text { Control } \\
\text { (DD } \\
\text { water) } \\
\text { EC } \\
(0.0 \\
\text { dS } / \mathrm{m})\end{array}$ \\
\hline 1 & SM-11-44 & 1166.67 & 0.278 & 135.5 & 0.861 & 422.5 & 9.12 & 18.44 & 5.7 & 10.94 \\
\hline 2 & SM-11-41 & 1286.10 & 0.306 & 150.0 & 0.707 & 343.0 & 5.14 & 9.14 & 5.8 & 9.8 \\
\hline 3 & SM-11-38 & 1183.33 & 0.230 & 111.5 & 1.009 & 501.5 & 15.64 & 19.14 & 7.28 & 15.06 \\
\hline 4 & SM-11-45 & 1186.11 & 0.288 & 139.5 & 1.08 & 533.5 & 3.16 & 6.99 & 5.9 & 15.02 \\
\hline 5 & SM-11-24 & 1166.67 & 0.275 & 138.5 & 0.765 & 375.5 & 11.32 & 23.02 & 7.22 & 13.68 \\
\hline 6 & KM-11-557 & 1158.33 & 0.249 & 121.5 & 0.991 & 468.0 & 12.82 & 15.50 & 11.2 & 14.70 \\
\hline 7 & KM-11-578 & 1211.10 & 0.296 & 162.0 & 0.831 & 403.5 & 13.5 & 15.0 & 6.58 & 7.5 \\
\hline 8 & KM-11-583 & 1280.55 & 0.300 & 146.5 & 1.040 & 521.0 & 18.42 & 28.5 & 7.82 & 13.94 \\
\hline 9 & KM-11-573 & 1302.77 & 0.270 & 137.5 & 1.043 & 340.1 & 10.2 & 16.24 & 7.38 & 10.30 \\
\hline 10 & KM-11-563 & 1139.71 & 0.263 & 127.0 & 0.812 & 372.0 & 14.4 & 21.54 & 9.8 & 13.74 \\
\hline 11 & KM-11-587 & 1202.77 & 0.239 & 116.0 & 0.727 & 352.5 & 8.49 & 17.18 & 6.1 & 8.04 \\
\hline 12 & PUSA-2031 & 1398.05 & 0.249 & 129.0 & 0.887 & 472.5 & 18.18 & 20.44 & 11.64 & 14.76 \\
\hline 13 & ML-5 & 1205.55 & 0.266 & 131.0 & 0.604 & 299.0 & 6.62 & 16.22 & 7.84 & 13.42 \\
\hline 14 & KM-52 & 1194.44 & 0.294 & 140.5 & 0.933 & 513.5 & 17.24 & 19.0 & 10.52 & 14.92 \\
\hline 15 & VM-44-97-1 & 1116.66 & 0.281 & 145.5 & 1.224 & 623.0 & 16.36 & 24.42 & 9.04 & 11.92 \\
\hline 16 & $\begin{array}{c}\text { Chaiti } \\
\text { Moong } \\
\text { (Local } \\
\text { Check) }\end{array}$ & 797.22 & 0.299 & 154.5 & 0.972 & 478.5 & 3.38 & 14.48 & 3.28 & 13.42 \\
\hline & LSD $(5 \%)$ & 114.2 & N.S. & N.S. & 0.268 & 34.3 & 2.19 & 1.42 & 0.81 & 0.58 \\
\hline & C.V (\%) & 9.7 & - & - & 6.5 & 8.2 & 6.3 & 4.7 & 3.7 & 4.2 \\
\hline
\end{tabular}

From the findings, it can be concluded that higher value of the above discussed yield attributing traits in medium to high saline soil indicated the soil salinity tolerance behavior of the green gram genotypes. Selection of a promising genotype of green gram for cultivation in coastal saline belts of West Bengal is required. The root behavior/ characteristics in field as well as laboratory condition in medium to high salinity level may help the agriculturists for selection/identification of good green gram genotypes suitable for growing in coastal saline belts like Sundarbans regions. The finding is supported by the findings of Mishra and Trevedi (2004), Ashraf and Rasul (1997) and Greg and Smith (1962).

The findings also highlighted that in higher salinity level the higher numbers of root branches (in laboratory or in field condition) is the key indicator for the salinity tolerant behavior of the green gram. Early root and shoot characteristics study is also useful for selection of a salinity tolerance green gram genotype. Similar findings were also reported by Singh, Malick and Sharma (1989), Epestein (1985) and More and Gourisankar (1982). 


\section{Conclusion}

From the above experiment it may be concluded that in the similar agro-climatic condition as well as soil salinity condition the above genotypes may prove to perform better than the local cultivar, Chaiti moong being cultivated in the coastal saline regions of Sundarbans, West Bengal. From the experimental findings, it may be concluded that the cultivar like PUSA-2031, KM-11-573, SM11-41, KM-11-583, KM-11-578 may be advised to be grown successfully in limited irrigation source in the low to medium saline soil when Electrical Conductivity of the soil is below $1.5 \mathrm{dS} / \mathrm{m}$. The result of the experiment also indicates that the green gram can be grown profitably in coastal saline belts of Sundarbans as a rainfed crop with minimum irrigation facilities where the EC level of the soil does not exceed $1.5 \mathrm{dS} / \mathrm{m}$ and availability of soil nitrogen, phosphate, potash and organic carbon is optimum if the cultivation may done with any of the above genotypes.

\section{References}

Ashraf, M. and Rasul, E. (1997). Salt tolerance of mung bean cultivars (Vigna radiata L.) at two growth stages. Plant and Soil, 110(1): 63-67.

Epestein, A.K. (1985). Performance of mung bean cultivars affected by moisture stress and soil salinity. Plant and Soil, 58(1): 163-170.

Ghassemi, F., Jackman, A.J. and Nix, H.A. (1995). Salinization of land and water resources: Human causes, extent, management and case studies. Sydney, Australia: UNSW Press.

Greig, J.K. and Smith, F.W. (1962). Salinity effects on green gram growth. Agron. J., 42(2):145150.

Mass, N.J. and Haffman, S.J. (1977). Effect of soil salinity on various pulse crop in rainfed condition. Plant and Soil, 41: 225-232.

Mishra, J.N. and Trivedi, U.N. (2004). Genotypic differences in salinity tolerance of green gram (Vigna radiata (L.) Wilczek) cultivars. Plant Sci., 66: 1135-1142.

More, S.S and Gourishankar, C.P. (1982). Salt tolerance studies on green gram (Vigna radiata L.) cultivars. J. Maharashtra Agric. Univ., 7: 245-252.

Singh, H., Malick, B.P. and Sharma, H.C. (1989). Relative performance of mung bean cultivars (Vigna radiata (L.) Wilczek) under various level of soil salinity. Harryana J. Agron., 5(2): $171-173$. 